\title{
Preparation and Characterization of NiTi Shape Memory Alloy Preparedby Powder Metallurgy
}

\author{
Vojtěch Kučera, Jaroslav Čapek, Alena Michalcová, Dalibor Vojtěch \\ Department of Metals and Corrosion Engineering, Institute of Chemical Technology, Prague, Technická 5, 16628 Prague \\ 6, Czech Republic. E-mail: kucerao@vscht.cz.
}

\begin{abstract}
Some perspective materials are characterized by shape memory effect and NiTi alloy belongs to their main representatives. NiTi is an approximately equiatomic alloy of nickel and titanium and it possesses interesting properties, such as superelasticity, pseudoplasticity and good corrosion resistance. Hence, it is used in different branches of industry (aerospace, medicine, engineering etc.). Common manufacturing melting methods of this alloy are vacuum arc remelting (VAR) and vacuum induction melting (VIM) methods. However, these methods have some disadvantages. The VAR process must be repeated several times to achieve sufficient homogeneity of manufactured ingots. During the VIM process the melt can be contaminated by carbon originated from graphite crucible. Therefore, powder metallurgical methods have been extensively investigated in last years as an alternative to the common processes. In this work, NiTi samples were prepared by the thermale xplosion mode of self-propagating high-temperature synthesis (TE-SHS). Chemical and phase composition, as well as microstructure and hardness of the prepared samples were studied. Afterwards, the samples were heat treated and the influence of the annealing on the studied characteristics was investigated.
\end{abstract}

Keywords: NiTi alloy, powder metallurgy, SHS

\section{Acknowledgement}

The authors would like to thank to the Czech science foundation (project no. P108/12/G043).

\section{References}

[1] NOVÁK, V. (2003). Intermetalika a jevy tvarové paměti. http://archiv.otevrena-veda.cz/users/Image/default/C2Seminare/MultiObSem/003.pdf (accessed March 10, 2013), Czech Republic.

[2] BELAN, J. (2013). Study of advanced Ni - base ZS6K alloy by quantitative metallography methods. In: Manufacturing Technology, Vol. 13, No. 1, pp. 2-7, Czech Republic.

[3] ZANABONI, E. (2008). One Way and Two Way-Shape Memory Effect: Thermo-Mechanical Characterization of Ni-Ti wires. Corso di Laurea Magistrale, Universit 'a degli Studi di Pavia, France.

[4] PELton, A. R., RUSSELl, S. M., DICELLO, J. (2003). The Physical Metallurgy of Nitinol for Meddical Applications. In: JOM-Journal of the Minerals, Metals and Materials Society, Vol. 55, No. 5, pp. 33 - 37, USA.

[5] NAYAN, N., GOVIN, D., SAIKRISHNA, C. N., VENKATA R. K., BHAUMIK, S. K., SUSEELAN N., K., MITTAL, M. (2007). Vacuum induction melting of NiTi shape memory alloys in graphite crucible. In: Materials Science and Engineering A, Vol. 462, No. 1 - 2, pp. 44 - 48, Nederland.

[6] FRENZEL, J., ZHANG, Z., NEUKING, K., EGGELER, G. (2004). High quality vacuum induction melting of small quantities of NiTi shape memory alloys in graphite crucibles. In: Journal of Alloys and Compounds, Vol. 385 , No. $1-2$, pp. $214-223$, Switzerland.

[7] ELAHINIA, M. H., HASHEMI, M., TABESH, M., BHADURI, S. B. (2012). Manufacturing and processing of NiTi implants: A review. In: Progress in Materials Science, Vol. 57, No. 5, pp. 911 - 946, England.

[8] LIU, G., Li, J., CHEN, K. (2012). Combustion synthesis of refractory and hard materials: A review. In: Int. Journal of Refractory Metals and Hard Materials, Vol. 39, No. SI, pp. 90 - 102, England.

[9] NOVÁK, P., MICHALCOVÁ, A., MAREK, I., VODĚROVÁ, M., VOJTĚCH, D. (2012). Possibilities of the observation of chemical reactions during the preparation of intermetallics by reactive sintering. In: Manufacturing Technology, Vol. 12, No. 2, pp. 197 - 201, Czech Republic.

[10] WHITNEY, M., CORBIN, S., GORBET, R., et al. (2008). Investigation of the mechanisms of reactive sintering and combustion synthesis of NiTi using differential scanning calorimetry and microstructural analysis. In: $A c$ taMaterialia, Vol. 56, No. 3, pp. 559 - 570, England.

[11] BISWAS, A. (2005). Porous NiTi by thermal explosion mode of SHS:processing, mechanism and generation of single phase microstructure. In: Acta Materialia, Vol. 53, No. 6, pp. 1415 - 1425, England. 
[12] KAJIKAWA, K., OIKAWA, K., TAKAHASHI, F., YAMADA, H., ANZAI, K. (2010). Reassessment of Liquid/Solid Equilibrium in Ni-Rich Side of Ni-Nb and Ni-Ti Systems. In: Materials Transactions, Vol. 51, No. 4, pp. 781 - 786, Japan.

[13] WEISS, V., KVAPILOVA, I. (2013). Assessment of the effect of temperature and annealing time homogenization $\mathrm{AlCu} 4 \mathrm{MgMn}$ alloys in terms of microstructure image analysis methods and EDX. In: Manufacturing Technology, Vol. 13, No. 1, pp. 123 - 127, Czech Republic.

[14] MENTZ, J., FRENZEL, J., MARTIN, F., WAGNER, X., NEUKING, K., EGGELER, G., BUCHKREMER, H. P., STOVER, D. (2008). Powder metallurgical processing of NiTi shape memory alloys with elevated transformation temperatures. In: Materials Science and Engineering: A, Vol. 491, No. 1 - 2, pp. 270 - 278, Switzerland.

[15] MOTEMANI, Y., NILI-AHMADABADI, M., TAN, M. J., BOMAPOUR, M., RAYAGAN, S. (2009). Effect of cooling rate on the phase transformation behavior and mechanical properties of Ni-rich NiTi shape memory alloy. In: Journal of Alloys and Compounds, Vol. 469, No. 1 - 2, pp. 164-168, Switzerland.

[16] QIAN, L., SUN, Q., XIAO, X. (2006). Role of phase transition in the unusual microwear behavior of superelastic NiTi shape memory alloy. In: Wear, Vol. 260, No. 4-5, pp. $509-522$, Switzerland. 